3. Porfirev, B. N. (2016). «Zelenye» tendencii v mirovoj finansovoj sisteme [«Green» trends in the world financial system]. Mirovaia ekonomika i mezhdunarodnye otnoshenia - World Economy and International Relations, 9, 5-16 [in Russian].

4. Kramar, O. (2017) Ne toi vidtinok zelenoho [Not that green]. Ukrainskyi tyzhden - Ukrainian history, 7, 14-17 [in Ukrainian].

5. Piketti, T. (2016). Kapital u XX stolitti [Capital in the twentieth century]. Nash Format-Our Format, 696 [in Ukrainian].

Стаття надійшла до редакції 26.01.2019 р.

\author{
Borysiuk Olena, \\ PhD in Economics, Associate Professor, \\ Lesia Ukrainka Eastern European national university \\ Department of finances, bank business and insurance \\ Lytsk; ORCID ID 0000-0002-9411-4118 \\ e-mail: lena_borysuk@ukr.net \\ Datsyuk-Tomchuk Maria, \\ PhD in Economics, Associate Professor, \\ Department of Law and Finance \\ Lytsk; ORCID ID 0000-0002-9794-8943 \\ e-mail: mashaprof@ukr.net \\ https://doi.org/10.29038/2411-4014-2019-01-100-106
} Lutsk Institute of Human Development of the University of «Ukraine»

\title{
PROBLEMS OF LIFE INSURANCE DEVELOPMENT IN TERMS AN UNSTABLE FINANCIAL ENVIRONMENT
}

In modern conditions, life insurance plays a crucial role for the economy of the country and its citizens, because it is aimed at financial and social protection of the population through the organization of an integrated system of material security in the event of various events associated with life, health, disability or other events, which can lead to a significant imbalance of family or personal budgets, and a decline in living standards.

The main trends of life insurance development in Ukraine presented in the study demonstrate that current processes of globalization have a serious impact on the complications of consumer and savings properties of life insurance through the merger of insurance, credit and investment products.

At the same time, in Ukraine, this type of insurance is hampered by a number of factors, due to which it does not become widespread. That is why the article focuses on the problems of life insurance development in the context of financial imbalances and proposes directions for their activation in Ukraine.

Key words: life insurance; insurance payments, accumulative life insurance; insurance product; life insurance reserves.

Борисюк Олена, кандидат економічних наук, доцент, Східноєвропейський національний університет імені Лесі Українки кафедра фінансів, банківської справи та страхування; м. Луцьк; ORCID ID 0000-0002-9411-4118 e-mail: lena-borysuk@ukr.net

Дацюк-Томчук Марія, кандидат економічних наук, доцент, Луцький інститут розвитку людини Університету «Україна» кафедра права та фінансів

м. Луцьк, ORCID ID 0000-0002-9794-8943 e-mail:mashaprof@ukr.net

\section{ПРОБЛЕМИ РОЗВИТКУ СТРАХУВАННЯ ЖИТТЯ В УМОВАХ НЕСТАБІЛЬНОГО ФІНАНСОВОГО СЕРЕДОВИЩА}

В сучасних умовах страхування життя грає найважливішу роль для економіки країни і їі громадян, оскільки воно направлено на фінансовий і соціальний захист населення за допомогою організації комплексної системи матеріального 
забезпечення при настанні різних подій, пов’язаних з життям, здоров’ям, працездатністю або іншими обставинами, які можуть привести до значного дисбалансу сімейного або особистого бюджету, зниження рівня життя.

Представлені в дослідженні основні тенденції розвитку страхування життя в Україні наочно демонструють, що процеси глобалізації, що відбуваються в даний час, роблять серйозний вплив на ускладнення споживчих і накопичувальних властивостей страхування життя за рахунок злиття страхового, кредитного та інвестиційного продуктів.

Варто відмітити, що метою стимулювання розвитку страхування життя в європейських країнах є надання цілої система фінансових пільг для довгострокового страхування життя. Так, наприклад, в ряді країн податок на страхові виплати за такими договорами нижче, ніж на дохід по банківських депозитах. В інших країнах діють податкові пільги на страхові внески, які сплачуються за довгостроковими договорами страхування життя, надаються пільги і на оподаткування інвестиційного доходу від розміщення страхових резервів. У звязку із цим у розвинених країнах страхові компанії життя є найбагатшими фінансовими інститутами, які акумулюють значно більше коштів, ніж банки. Так, резерви таких страховиків становлять сотні мільярдів доларів США. Накопичувальне страхування життя - найбільш поширений вид страхування в Західній Свропі, Америці і Японії. Проте в Україні даний вид страхування стримують ряд факторів, завдяки чому воно не набуває широкого розвитку. Саме тому в статті акцентовано увагу на проблемах розвитку страхування життя в умовах фінансових дисбалансів та запропоновано напрямки їх активізації в Україні.

Ключові слова: страхування життя; страхові платежі, накопичувальне страхування життя; страховий продукт; резерви зі страхування життя.

Борисюк Елена, кандидат экономических наук, доцент, Восточноевропейский национальный университет, имени Леси Украинки кафедра финансов, банковского дела и страхования; г. Луцк; ORCID ID 0000-0002-9411-4118 e-mail: lena_borysuk@ukr.net

Дацюк-Томчук Мария, кандидат экономических наук, доцент, Луцкого института развития человека университета «Украина» кафедра права и финансов м. Луцк; ORCID ID 0000-0002-9794-8943 e-mail: mashaprof@ukr.net

\section{ПРОБЛЕМЫ РАЗВИТИЯ СТРАХОВАНИЯ ЖИЗНИ В УСЛОВИЯХ НЕСТАБИЛЬНОЙ ФИНАНСОВОЙ СРЕДЫ}

В современных условиях страхование жизни играет важнейшую роль для экономики страны и ее граждан, поскольку оно направлено на финансовую и социальную защиту населения посредством организации комплексной системы материального обеспечения при наступлении различных событий, связанных с жизнью, здоровьем, трудоспособностью или другими обстоятельствами, которые могут привести к значительному дисбалансу семейного или личного бюджета, снижение уровня жизни.

Представленные в исследовании основные тенденции развития страхования жизни в Украине наглядно демонстрируют, что процессы глобализации, происходящие в настоящее время, оказывают серьезное влияние на осложнение потребительских и накопительных свойств страхования жизни за счет слияния страхового, кредитного и инвестиционного продуктов.

Стоит отметить, что целью стимулирования развития страхования жизни в европейских странах является предоставление целой системы финансовых льгот для долгосрочного страхования жизни. Так, например, в ряде стран налог на страховые выплаты по таким договорам ниже, чем на доход по банковским депозитам. В других странах действуют налоговые льготы на страховые взносы, уплачиваемые по долгосрочным договорам страхования жизни, предоставляются льготы и на налогообложение инвестиционного дохода от размещения страховых резервов. В связи с этим в развитых странах страховые компании жизни являются самыми богатыми финансовыми институтами, которые аккумулируют значительно больше средств, нежели банки. Так, резервы таких страховщиков составляют сотни миллиардов долларов США. Накопительное страхование жизни наиболее распространенный вид страхования в Западной Европе, Америке и Японии. Однако в Украине данный вид страхования сдерживают ряд факторов, благодаря чему оно не приобретает широкое развитие. Именно поэтому в статье акцентировано внимание на проблемах развития страхования жизни в условиях финансовых дисбалансов и предложены направления их активизации в Украине.

Ключевые слова: страхование жизни; страховые платежи, накопительное страхование жизни; страховой продукт; резервы по страхованию жизни. 
Formulation of scientific problem and its significance. According to the conducted researches, the relevance of the research topic is determined by the special role of life insurance in solving social problems of society, by providing social guarantees to the population, which in turn increases trust in the government and leads to the stabilization of the political and economic situation in the country. Insurance payments under the life insurance contracts reduce the spending part of the budget for the social programs, and the funds accumulated by the insurers are the source of significant long-term investments in the economy. In the developed countries the life insurance sector is a strategically important industry, which forms a solid foundation for a sustainable economic development.

An analysis of recent research on this problem. The problems of life insurance are dealt with by such domestic scientists as: T. M. Artyukh, V. D. Bazylevych, L. O. Boyko, G.L. Voznyuk, N .M. Vnukova, O. O. Gamankova, O. M. Zaletov, A. M. Yermoshenko, M. S. Klapkov, M. M. Mnyh, S. S. Osadets., R. V. Pikus, V. I. Plisa, T. A. Rotova, V. V. Furman, and also foreign ones - N. Galaguza, D. Blad, L. Pankov, L. Lozovsky, B. Rayzberg, T. Fedorova, O. Shakhov and others.

The purpose and objectives of the article. The purpose of the article is to analyze the main indicators of the development of the life insurance in Ukraine at the present stage, taking into account the prospects of its modernization in domestic conditions.

Presentation of the main material and the substantiation of the research results obtained. The economic essence of the insurance is inextricably linked with the concept of the insurance protection. Insurance comes from the word «fear». It is fear that gives rise to a person's desire to protect himself from the dangers. In a market economy, insurance is a universal means of insurance protection of the population and business. From the economic point of view, insurance protection allows you to prevent and reduce possible costs to cover losses at the onset of an insured event.

Life insurance is an important tool for infusing long-term investments into the economy through which the welfare of the population as a whole can increase. It is the investment function that manifests itself through the contracts of accumulation life insurance. According to the legal framework, the insurer, calculating the insurance rate for life insurance, adds an investment premium to the structure of the insurance tariff, which takes into account the interest rate and its changes in a specific time interval. In the case of risk insurance, the insurer may periodically experience a threat to insufficiency of the insurance fund upon occurrence of an insurance event and payment of insurance indemnity.

Considering insurance, one should not forget about the social function performed by insurance, including life insurance. Social function is expressed in the creation of the security of subjects, ensuring socio-economic stability in society. The state recognizes the need for social guarantees for the population, and their implementation is carried out through state-owned insurance companies that provide minimum guarantees through obligatory insurance. In foreign countries, private insurance companies actively participate in the realization of social insurance functions through voluntary insurance contracts.

In highly developed countries, life insurance companies have the following functions:

- raise the standard of living of persons of retirement age;

- increase confidence in tomorrow;

- provide additional social guarantees in case of temporary or permanent disability, loss of breadwinner;

- accumulating pension savings for investment in the economy;

- create social stability in society.

Due to this, life insurance companies have investment opportunities that make their position in the capital market unique. The reasons for this uniqueness are as follows:

- life insurance companies, unlike the other financial institutions, have the opportunity to attract free funds for a lower percentage, as such involvement takes place on the basis of providing insurance protection;

- the life insurance contract is concluded for a long time, with payments obligations separated in time, and they can be more likely to be forecasted.

Thus, life insurance benefits the state for two reasons. First, the funds accumulated by such insurance companies are domestic investments in the national economy. Secondly, by stimulating the development of life insurance, the state solves the problem of social security of citizens and transfers it to the shoulders of insurance companies.

In the insurance market of Ukraine, the total number of insurance companies as of September 30, 2018 amounted to 285 , including life insurance companies - 31 companies, non-life insurance companies - 254 companies (as at 30.09.2017 - 296 companies, including insurance companies «life» - 34 companies, 
insurance companies «non-life»- 262 companies). The number of insurance companies tends to decrease, as in 9 months of 2018 compared to the same period in 2017, the number of companies decreased by 11 insurers (table 1).

Table 1

Number of the insurance companies*

\begin{tabular}{|l|c|c|c|c|}
\hline \multirow{2}{*}{ Number of the insurance companies } & As of & As of & As of & As of \\
\cline { 2 - 5 } & $\mathbf{3 1 . 1 2 . 2 0 1 6}$ & $\mathbf{3 1 . 1 2 . 2 0 1 7}$ & $\mathbf{3 0 . 0 9 . 2 0 1 7}$ & $\mathbf{3 0 . 0 9 . 2 0 1 8}$ \\
\hline The total number & 310 & 294 & 296 & 285 \\
\hline including insurance companies «non-Life» & 271 & 261 & 262 & 254 \\
\hline including insurance companies «Life» & 39 & 33 & 34 & 31 \\
\hline
\end{tabular}

* Source [5]

Gross insurance payments (premiums, contributions) for life insurance during the 9 months of 2018 amounted to UAH 2741,1 million, which is by 35,6 \% more than in the nine months of 2017 (as at 30.09.2017 - 2021,7 million UAH).

The structure of gross receipts of the insurance payments (premiums, contributions) as of 09.30.2018 was as follows [2]:

$-2649,9$ mln. UAH (or 96,7 \%) - received from individuals;

- 91,2 mln. UAH (or $3,3 \%$ ) - received from legal entities.

As of September 30, 2018, the number of insured individuals increased by $0,3 \%$ or by 12017 persons (as of September 2017 - 4259945 individuals were insured, as at 30.09.2018 - 4271962 individuals).

During 9 months of $2017-2,329,720$ individuals were insured, which is 1,4 times or 1357557 persons more in comparison with the corresponding period of 2017 (during the 9 months of 2017 - 972163 individuals were insured).

The gross insurance premiums from the life insurance as of September 30, 2018 amounted to UAH 536,8 million, which is by $29,8 \%$ more compared to the corresponding period of 2017 (as of September 30, 2017 - UAH 413,6 million.)

The change in the life insurance reserves for the 9 months of 2017-2018 is shown in table 2.

Table 2

Change in the life insurance reserves for 9 months 2017-218

\begin{tabular}{|c|c|c|c|}
\hline \multirow{2}{*}{ Indication } & $\begin{array}{l}9 \text { months } \\
2017\end{array}$ & 9 months 2018 & \multirow{2}{*}{$\begin{array}{c}\text { Pace } \\
\text { gain, \% }\end{array}$} \\
\hline & \multicolumn{2}{|c|}{ million UAH } & \\
\hline Amount of changes in the life insurance reserves, including: & 452,7 & 748,0 & 65,2 \\
\hline investment income used to calculate insurance rates; & 166,0 & 185,1 & 11,5 \\
\hline $\begin{array}{l}\text { indexation of amounts of insurance sum and (or) insurance payments } \\
\text { according to the official index of inflation; }\end{array}$ & 42,2 & 59,2 & 40,3 \\
\hline $\begin{array}{l}\text { part of the investment income from the placement of the life } \\
\text { insurance reserves remaining after the statutory provisions of Article } \\
9 \text { of the Law of Ukraine «On Insurance» obligatory deductions in } \\
\text { mathematical reserves and deductions of expenses of the insurer for } \\
\text { the conduct of affairs; }\end{array}$ & 247,8 & 225,3 & $-9,1$ \\
\hline $\begin{array}{l}\text { the total amount of increase in the amount of insurance sum and (or) } \\
\text { insurance payments (bonuses), which are determined by the other } \\
\text { financial results of activity in accordance with the insurance } \\
\text { contracts, which provide for the insurer's participation in the } \\
\text { investment income of the insurer; }\end{array}$ & 10,8 & 21,8 & 101,9 \\
\hline $\begin{array}{l}\text { the magnitude of the change in the size of the insurance amounts and } \\
\text { (or) the insurance payments under the insurance contracts, monetary } \\
\text { liabilities determined in the freely convertible currency or the } \\
\text { estimated values. }\end{array}$ & 25,0 & 28,4 & 13,6 \\
\hline
\end{tabular}

* Source [2]

According to the results of 9 months of 2018, 7 insurance companies "Life" received a negative value of an increase in the life insurance reserves for a total amount of UAH 56,6 million, which is due to early termination of the insurance contracts (for the 9 months of 2017 - 12 insurance companies "Life" declared a 
negative value for the total amount of 130,7 million UAH). The increase in the life insurance reserves amounted to 804,6 million UAH. The largest increase in insurance reserves for life insurance (more than UAH 90 million) was declared by three insurance companies «Life» in the amount of UAH 275,9 million, and 144,3 million UAH and UAH 96,8 mln. $(34,3 \%, 17,9 \%$ and $12.0 \%$ of the total increase of reserves respectively) [1, p. 9].

The dynamics of the insurance payments for the life insurance during the investigated period is shown in table 3.

Table 3

Life insurance payments*

\begin{tabular}{|l|c|c|c|}
\hline \multirow{2}{*}{\multicolumn{1}{c|}{ The company name }} & \multicolumn{2}{c|}{ Insurance payments, ths. UAH } \\
\cline { 2 - 4 } & $\begin{array}{c}\mathbf{9} \text { months } \\
\mathbf{2 0 1 8}\end{array}$ & $\begin{array}{c}\mathbf{9} \text { months } \\
\mathbf{2 0 1 7}\end{array}$ & $\begin{array}{c}\mathbf{9} \text { months } \\
\mathbf{2 0 1 6}\end{array}$ \\
\hline MET LIFE & 432412,0 & 336248,0 & 277296,0 \\
\hline UNITY LIFE & 286630,0 & 195732,0 & 117772,0 \\
\hline TAS & 235774,0 & 209933,9 & 72611,0 \\
\hline ASKA-LIFE & 217598,0 & 94016,0 & 109498,2 \\
\hline $\begin{array}{l}\text { PZU UKRAINE } \\
\text { Life insurance }\end{array}$ & 193603,7 & 131423,8 & 15611,0 \\
\hline $\begin{array}{l}\text { AHA UKRAINE } \\
\text { Life insurance }\end{array}$ & 41145,0 & 26508,0 & 51965,0 \\
\hline $\begin{array}{l}\text { KNYAZHA LIFE } \\
\text { WINEN INSURANCE GROUP }\end{array}$ & 31237,2 & 26828,0 & 14086,2 \\
\hline INGO UKRAINE LIFE & 20246,5 & 19060,1 & 11363,0 \\
\hline KD-LIFE & 15916,0 & 12189,0 & H/д \\
\hline GRINVUD LIFE INSURANCE & 10919,7 & 1596,6 & $\mathbf{7 9 9 9 1 6 , 4}$ \\
\hline TOTAL & $\mathbf{1 4 8 5 4 8 2 , 1}$ & $\mathbf{1 0 5 3 5 3 5 , 4}$ & \\
\hline
\end{tabular}

* Drawn up according to the Insurance TOP magazine

The leaders in terms of the number of insured citizens during the research period are Met Life, AskaLife and TAS (table 4).

Table 4

Number of life insurance contracts and insured*

\begin{tabular}{|l|c|c|c|}
\hline \multicolumn{1}{|c|}{ The company name } & $\begin{array}{c}\text { Number of citizens } \\
\text { insured } \\
\text { September 30, 2018 }\end{array}$ & $\begin{array}{c}\text { The number } \\
\text { including } \\
\text { for 9 months } \\
\mathbf{2 0 1 8}\end{array}$ & $\begin{array}{c}\text { of insurance contracts } \\
\text { concluded for 9 } \\
\text { months of 2018 }\end{array}$ \\
\hline MET LIFE & 628751 & 687370 & 664617 \\
\hline ASKA-LIFE & 515136 & 152709 & 144637 \\
\hline TAS & 277684 & 65428 & 54305 \\
\hline UNITY LIFE & 209939 & 81825 & 70397 \\
\hline $\begin{array}{l}\text { PZU UKRAINE } \\
\text { Life insurance }\end{array}$ & 107952 & 57854 & 57831 \\
\hline $\begin{array}{l}\text { AHA UKRAINE } \\
\text { Life insurance }\end{array}$ & 52747 & 90506 & 81967 \\
\hline KNYAZHA LIFE & 14686 & 1720 & 1887 \\
\hline WINEN INSURANCE GROUP & 13550 & 12043 & 89 \\
\hline INGO UKRAINE LIFE & 7944 & 901 & 901 \\
\hline KD-LIFE & 3726 & 1804 & 3081 \\
\hline GRINVUD LIFE INSURANCE & $\mathbf{1 8 3 2 1 1 5}$ & $\mathbf{1 1 5 2 1 6 0}$ & $\mathbf{1 0 7 9 7 1 2}$ \\
\hline
\end{tabular}

* Drawn up according to the Insurance TOP magazine

At the present stage, the most popular products of life insurance companies are:

- life insurance pension insurance; 
- pension insurance for general and professional incapacity;

- family life insurance pension insurance;

- survivor's pension insurance;

- temporary pension insurance.

In recent years, insignificant growth in the life insurance market in Ukraine has taken place. This is primarily due to an increase in business activity in the country, which in turn led to an increase in the welfare of the population. It is also worth taking into account the active work of life insurance companies that have been created over the last 3 years, which use modern forms and methods of sales of insurance services. However, there are problems that impede the development of life insurance in Ukraine, namely [3, p.40]:

- a negative impact of the population on life insurance in the post-Soviet period;

-instability of the political situation;

-lack of a legislative framework which would guarantee the preservation of invested funds and transparency of investment instruments.

- lack of the appropriate traditions of the life insurance;

- inflation, instability of the national currency;

- unability of the population and enterprises to buy insurance services in the absence of free cash;

- a large number of insurance companies with a low level of capitalization, as well as a weak development of the national reinsurance market;

- contradictory insurance law;

- unfavorable tax legislation;

- insufficient capacity of the insurance market.

At the same time, in order to stimulate the development of the life insurance in European countries there is a whole system of financial benefits for the long-term life insurance. For example, in a number of countries, the tax on insurance payments under such contracts is lower than the income on bank deposits. In the other countries there are tax deductions for insurance premiums, which are paid under the long-term life insurance contracts, there are granted benefits and tax on investment income from the placement of insurance reserves.

In all developed countries, insurance companies are the richest financial institutions. They accumulate significantly more money than banks. The reserves of the largest insurers are hundreds of billions of dollars. Accumulation life insurance is the most common type of insurance in Western Europe, America and Japan.

That is why there is a need to modernize the sphere of the life insurance in Ukraine. In this context, it is worthwhile to:

- political and economic stability in the country and completion of privatization processes in the main sectors of the national economy, since insurance protection is possible only for the owner of certain economic benefits and in the conditions of the effective functioning of the financial system;

- increasing cooperation between the state and insurance companies in the direction of developing programs of additional social protection of citizens;

- improvement of the risk management mechanism through the maximum automation of life insurance, which will enable insurers to quickly process large arrays of medical databases (automatic underwriting);

- increasing the quality of insurance products for the life insurance and the qualifications of insurers in the specified area of insurance, especially medical underwriters;

- development of insurance mediation in terms of promoting the activity of insurance life insurance brokers.

Conclusions and perspectives of further research. Thus, such kind of insurance service as the life insurance, can minimize the consequences of social risks, give a guarantee of safety, improve the quality of human life, provide additional financial support. Many people are already engaged in the search for such instruments, attracting their own funds, as there is a growing need for additional forms of social protection, in self-management of social risks. In order to change the situation on the life insurance market in the direction of improvement, it is necessary to take decisive measures in the near future, namely: to develop transparent principles for the activity of insurers in Ukraine; to allow enterprises to include in their gross expenses the expenses for life insurance of their employees by changing the tax system through legislation; provide protection through the long-term insurance, such as life, health and pension programs at the legislative level. That is, to develop and formulate a concept for the further development of life insurance. 
The state, in the first place, is interested in developing life insurance, as it will increase the social protection of the population and raise additional funds into the economy through a new flow of the long-term investments.

\section{Джсерела та література}

1. Артюх Т. М. Страхування життя в умовах сучасного страхового ринку України Фінанси, облік і аудит. 2011. № 18. C. 9-15.

2. Інформація про стан і розвиток страхового ринку України за 9 міс. 2018 p. URL: https://www.nfp.gov. ua/files/OgliadRinkiv/SK/2018_rik/9_mis_2018/sk_9_mis_2018.

3. Карлін М. І. Борисюк О. В. Управління державними фінансами: посібник. Луцьк : ПП Іванюк , 2013. $273 \mathrm{c}$.

4. Малинич, Г. М. Порівняльний аналіз розвитку ринку страхування життя у країнах світу. Соиіально-економічні проблеми і держава. 2011. Вип. 1 (4) URL: http://sepd. tntu.edu.ua/images/stories/pdf/2011/11mhhuks.

5.Top Life insurance companies 2018. URL: http://www.thebestlifeins.com/top-Ufe-insurance-companies/world-assets.

\section{References}

1. Artyukh T. (2011). Strakhuvannja zhyttja v umovakh suchasnogho strakhovogho rynku Ukrajiny [Life insurance in the conditions of modern insurance market of Ukraine]. Finansy, oblik $i$ audyt, 18, pp. 9-15 [in Ukrainian].

2. Information on the status and development of the insurance market of Ukraine in 9 months 2018. Retrieved from: https://www.nfp.gov.ua/files/OgliadRinkiv/SK/2018_rik/9_mis_2018/sk_9_mis_2018. [in Ukrainian].

3. Karlin M. I. Borysjuk O. V. (2003), Upravlinnja derzhavnymy finansamy [Public finance management], Lucjk: PP Ivanjuk. pp.273 [in Ukrainian].

4. Malynych, G. (2011). Porivnjaljnyj analiz rozvytku rynku strakhuvannja zhyttja u krajinakh svitu. [Comparative analysis of the development of the life insurance market in the countries of the world.]. Socialjno-ekonomichni problemy i derzhava. Vol. 1 (4). Retrieved from: http://sepd. tntu.edu.ua/images/stories/pdf/ 2011/ 11mhhuks [in Ukrainian].

5. Top life insurance companies 2018. Retrieved from: http://www.thebestlifeins.com/top-life-insurancecompanies/world- assets [in Ukrainian].

Стаття надійшла до редакції 15.02.2019 р.

УДК 336.143:336.22(477)

Цимбалюк Ірина кандидат економічних наук, доцент, Східносвропейський національний університет імені Лесі Українки, кафедра фінансів, банківської справи та страхування; м. Луцьк; ORCID ID 0000-0001-7224-2365 e-mail: tsymbaliuk.ir@gmail.com https://doi.org/10.29038/2411-4014-2019-01-106-115

\section{ОСОБЛИВОСТІ ФУНКЦІОНУВАННЯ ПОДАТКОВОЇ СИСТЕМИ УКРАЇНИ ТА ОЦІНКА ЇЇ ФІСКАЛЬНОЇ ЕФЕКТИВНОСТІ}

У статті проаналізовано доходи зведеного бюджету України, визначено роль податкових надходжень та основні фактори, що впливають на їх обсяг. Проведено аналіз динаміки прямих та непрямих податків. 3'ясовано, що основну частину податкових надходжень формують податок на доходи фізичних осіб, податок на прибуток, ПДВ та акцизний податок. Здійснено оцінку фіскальної ролі, виявлено тенденції та наведено основні чинники, що визначали динаміку надходжень до зведеного бюджету найбільш значимих податків. Проведено оцінку фіскальної ефективності податкової системи України на основі їі порівняння із податковими системами країни ЄС за показником податкового навантаження та із врахуванням результатів рейтингу Doing Business.

Ключові слова: податкова система, зведений бюджет, податок на прибуток, податок на доходи фізичних осіб, податок на додану вартість, акцизний податок, податкове навантаження. 